\title{
Evaluation of Degradation of Heat Stressed Pipelines
}

\section{Sylvia Kusmierczak}

Faculty of Production Technology and Management, J. E. Purkyne University in Usti nad Labem. Pasteurova 3334/7, 400 01 Usti nad Labem. Czech Republic. E-mail: kusmierczak@fvtm.ujep.cz

Piping systems of boilers are mainly exposed by high temperatures, pressures and corrosive loads. This corresponds to the choice of materials boiler pipeline. These materials are in most cases special stainless steel for energetic equipment. Article deals with the evaluation of the resulting degradation of thermally stressed pipe boiler, which occurred after the increase boiler capacity. Degradation showed an increased amount of corrosion products on the inner surface of the pipeline, which resulted in clogging of pipes, formation of cracks and leakage of steam. Complex analysis was carried out of corrosion products and material microstructure pipelines. The result was that occurred to intergranular corrosion of pipelines in loaded state. On the basis of this was carried out analysis of the material in the unloaded state. Chemical composition and microstructure correspond to prescribed standards and requirements. Test of resistance to intergranular corrosion revealed that in the steel causing damage to the cohesion of the material along grain boundaries. It is for this type of material inadmissible. Therefore it is necessary in the case of increasing the performance of the boiler and thus the increase in temperature and pressure, to ensure a higher resistance to intergranular corrosion of the material.

Keywords: Degradation, Pipelines, Microstructures, Complex analysis.

\section{References}

[1] DVORAK, I. (2003). Degradační procesy a mezní stavy. VA Brno.

[2] HAJdUCHOVA, L., PESLOVA, F., STODOLA, P., STODOLA J. (2015). Degradation of propeller shaft surface during mechanical processing, In. ICMT 2015 - International Conference on Military Technologies.

[3] LASEK, S. (2012) Základy degradačních procesů. VŠB - Technická univerzita Ostrava.

[4] STODOLA, J., PESLOVA, F., KRMELA, J. (2008). Opotřebení strojních součástí. Univerzita obrany Brno, 197 s., ISBN 978-80-7231-552-9.

[5] KUSMIC, D., DOBROCKY, D. (2015). Corrosion Resistance of Plasma Nitrided Structural Steels. In: Manufacturing Technology, 2015, Vol. 15, No. 1, pp. 64-69. ISSN 1213-2489.

[6] CIHAL, J. (1999). Korozivzdorné oceli a slitiny. Academia, Praha.

[7] CIHAL, V. (1987). Mezikrystalová koroze korozivzdorných ocelí. SNTL Praha.

[8] MICHNA, S., KUSMIERCZAK, S. (2012). Praktická metalografie. FVTM UJEP, OPTYS, 245 s., ISBN 978-807414-503-2.

[9] MICHNA, S., KUSMIERCZAK, S., BAJCURA, M. (2010). Metalografie - metody a postupy. 1. vyd. Adin, 192 s., ISBN 978-80-89244-74-4.

[10] MICHNA, S., NAPRSTKOVA, N. (2012). The use of fractography in the analysis of cracking after formed workpiece blank mechanical machining from the AlCuSnBi alloy. In: Manufacturing Technology, vol. 12, 2012, pp. 174-178.

[11]SERAK, J., VODEROVA, M., VOJTECH, D., NOVAK, P. (2014). Microstructure and properties of magnesium alloys working at elevated temperatures. In. Manufacturing Technology, Vol. 14, No. 2, pp. 238-244.

[12]Bystriansky, J. (2012). Charakter oxidových vrstev. Metal. 